\title{
The Evolution of Refugee Determination in Gender-Related Claims: The Canadian Experience
}

\author{
Krista Daley
}

\begin{abstract}
In this paper, the author presents an overview of the evolution of gender-related issues in the determination of refugees in Canada. The question of whether a state can adequately protect a woman from gender-related persecution emerges from her analysis and places feasibility study at the apogee of directions for research.

\section{Précis}

Dans cet article, l'auteur présente un aperçu de l'évolution des questions relatives au sexage dans la détermination des détenteurs de statut de réfugié au $\mathrm{Ca}$ nada. Laquestionde savoir si unétat peut protéger adéquatement une femme des persécutions fondées sur le sexageémerge del'analyse et place les études de faisabilité au faite des directions de recherched envisager.
\end{abstract}

Since themid- 1980 s, refugeedetermination for women refugee claimants who fear gender-related persecution has been evolving and progressing in the international arena. The issues surrounding gender-related persecution have been discussed, modified, enhanced and more clearly articulated such that today there is a far greater understanding of the issues and a better appreciation of the legal analysis which is required for these types of refugee claims. At the Immigration and Refugee Board of Canada(IRB), there has been a similarevolution and progression in the issues to be resolved.

A female refugee claimant must satisfy the definition of the Convention refugee ${ }^{1}$ which provides as follows:

"Convention refugee" means any person who by reason of a wellfounded fear of persecution for reasons of race, religion, nationality,

Krista Daley is Senior Legal Advisor, Immigration and Refugee Board, Toronto, Canada. membership in a particular social group or political opinion is outside the country of the person's nationality, or country of former habitual residence, and is unable or, by reason of that fear, is unwilling to avail himself of the protection of that country.

A workable analytical framework which can be used to make an assessment of whether a woman refugeeclaimant satisfies this definition is as follows:

1. Is the harm which she fears "persecution", that is, a serious violation of a fundamental human right?

2. If the harm is persecution, then is the persecution going to occurby reason of her race, religion, nationality, membership in a particular social group or political opinion?

3. If yes, then is the fear of persecution well founded and, in particular, is there state protection available to her?

Since the IRB started in 1989, there has been a systematic progression of the issues surrounding claims of women. At the outset, some claims of genderrelated persecution would not make it past the first part of theanalytical framework outlined above whereas today many claims seem to be resolved at the third and final stage of the framework.

Initially, there was some doubt as to whether gender-specific forms of persecution would fit within the concept of persecution in the Convention refugee definition. As stated in the Canadian Guidelines on Women Refugee Claimants Fearing Gender-Related Persecution

The circumstances, which give rise to women's fear of persecution are often unique to women. The existing bank of jurisprudence on the meaning of persecution is based on, for the most part, the experiences of male claimants. Aside from a few cases of rape, the definition has not been widely applied to female-specific experiences, such as infanticide, genital mutilation, bride-burning, forced marriage, domestic violence, forced abortion, or compulsory sterilization.

Generally, gender-specific forms of human rights violations have been found by the Immigration and Refugee Board $^{2}$ and by the Federal Court of Canada $^{3}$ to amount to persecution. Thus, the first part of the analytical framework should nolonger be considered a contentious legal issue in the Canadian context.

The second part of the frameworkhas alsoevolved in thelast few years. As can be seen from the Convention refugee definition itself, persecution by reason of "gender" is not explicitly mentioned. However, following the SupremeCourt of Canada decision in Ward, ${ }^{4}$ the ground of "membership in a particular social group" proved to be broad enough to cover "women". Thus, a woman who fears gender-related persecution can argue that this is by reason of her gender. Since the Ward decision, there has been some debate as to whether the group should bebroadly defined as "women" or whether a more particular group, such as "women subject to domestic abuse," ${ }^{16}$ is more appropriate. The positive progression is that, rather than challenging theexistence of a group, the challenge has been to properly articulate the group.

As a result of a resolution of the second part of the analytical framework, the final part of the analysis is being reached more often in gender-related claims and many claims of gender-related persecution seem to comedown to an assessment of whether there is state protection available. The analysis involves an assessment of four questions:

1) What has the state done, or not done, for the woman in the past?

2) What has the state done, or not done, for similarly situated women in the past? 
3) What is the state willing or able to do about the persecution if the woman refugee claimant were to return to her country?

4) Is this adequate protection from the harm feared?

From these questions arises a legal question for resolution: what level of state protection is required to say that state protection is available and the fear of persecution is not well-founded. In the Canadian context, this seems to have been resolved by the Federal Court to be adequate but not perfect protection. ${ }^{7}$

In conclusion, it is always instructive to review the evolution of the law and to see how areas of legal contention are resolved. In the case of gender-related persecution, the analysis in Canada seems to have now evolved to the point where the central issue is-can a state adequately protect a woman from gender-related persecution?

\section{Notes}

1. Section 2(1) of the Immigration Act,as enacted by R.S.C. 1985(4th Supp.), c. 28, s.1. The full definition is:

"Convention refugee" means any person who: (a) by reason of a well-founded fear of persecution for reasons of race, religion, nationality, membership in a particular social group or political opinion,

(i) is outside the country of the person's nationality and is unable or, by reason of that fear, is unwilling to avail himself of the protection of that country, or

(ii) nothaving a country of nationality, is outside the country of the person's former habitual residence and is unable or, by reason of that fear, is unwilling to return to that country, and

(b) has not ceased to be a Convention refugee by virtue of subsection (2),

but does not include any person to whom the Convention does not apply pursuant to section $\mathrm{E}$ or $\mathrm{F}$ of Article 1 thereof, which sections are set out in the schedule to this Act.

2. For female genital mutiliation, see M9513161, Didier, Prévost, March 13, 1997 (reasons signed March 20,1997), and T9312198, Ramirez, McCaffrey, May 10, 1994. For forced sterilization, see V94-01287, Sachedina, Daggett, February 20, 1997. For forced marriage, see A96-00154, Showler, Gaboury (dissenting), June 11, 1997.

3. For female genital mutiliation, see Annanv. Canada (Minister of Citizenship and Immigration), [1995] 3 F.C. 25 (T.D.). For forced sterilization, see Cheung v. Canada (Minister of Employment and Immigration), [1993] 2 F.C. 314 (C.A.). For forced marriage, see Vidhani v. Canada (Minister of Citizenship and Immigration), [1995] 3 F.C. 60 (T.D.). For domestic violence, see Narvaez v. Canada (Minister of Citizenship and Immigration), [1995] 2 F.C. 55 (T.D.).

4. Canada (Attorney-General) v. Ward, [1993]2 S.C.R. 689

5. For examples of women being found to be the particular social group, see U9309915, Silcoff, Naqvi, August 9, 1994, V94-01548 Whitehead, Kalvin, May 15, 1995 (reasons signed March 24, 1997 and March 26, 1997), and T93-12198, Ramirez, McCaffrey, May 10, 1994.

6. For examples of narrower group articulation, see T93-04176 et al., Desai, Koulouras (dissenting), December7,1993, U95-04292, Allmen, Daya, October 2, 1996, and V94-01287, Sachedina, Daggett, February 20, 1997. In the Federal Court of Canada, Naroaez v. Canada (Minister of Citizenship and Immigration), [1995] 2 F.C. 55 (T.D.), Diluna v. Canada (Minister of Employment and Immigration) (1995), 29 Imm. L.R. (2d) 156 (F.C.T.D.), Litvinov, Svetlana v.S.S.C.(F.C.T.D., no.IMM-748893), Gibson, June 30, 1994.

7. Zalzali v. Canada (Minister of Employment and Immigration), [1991] 3 F.C. 605 (F.C.A.); (1991), 14 Imm. L.R. (2d) 81 and Canada (Minister of Employment and Immigration) v. Villafranca (1992), 18 Imm. L.R. (2d) 130 (F.C.A.). a

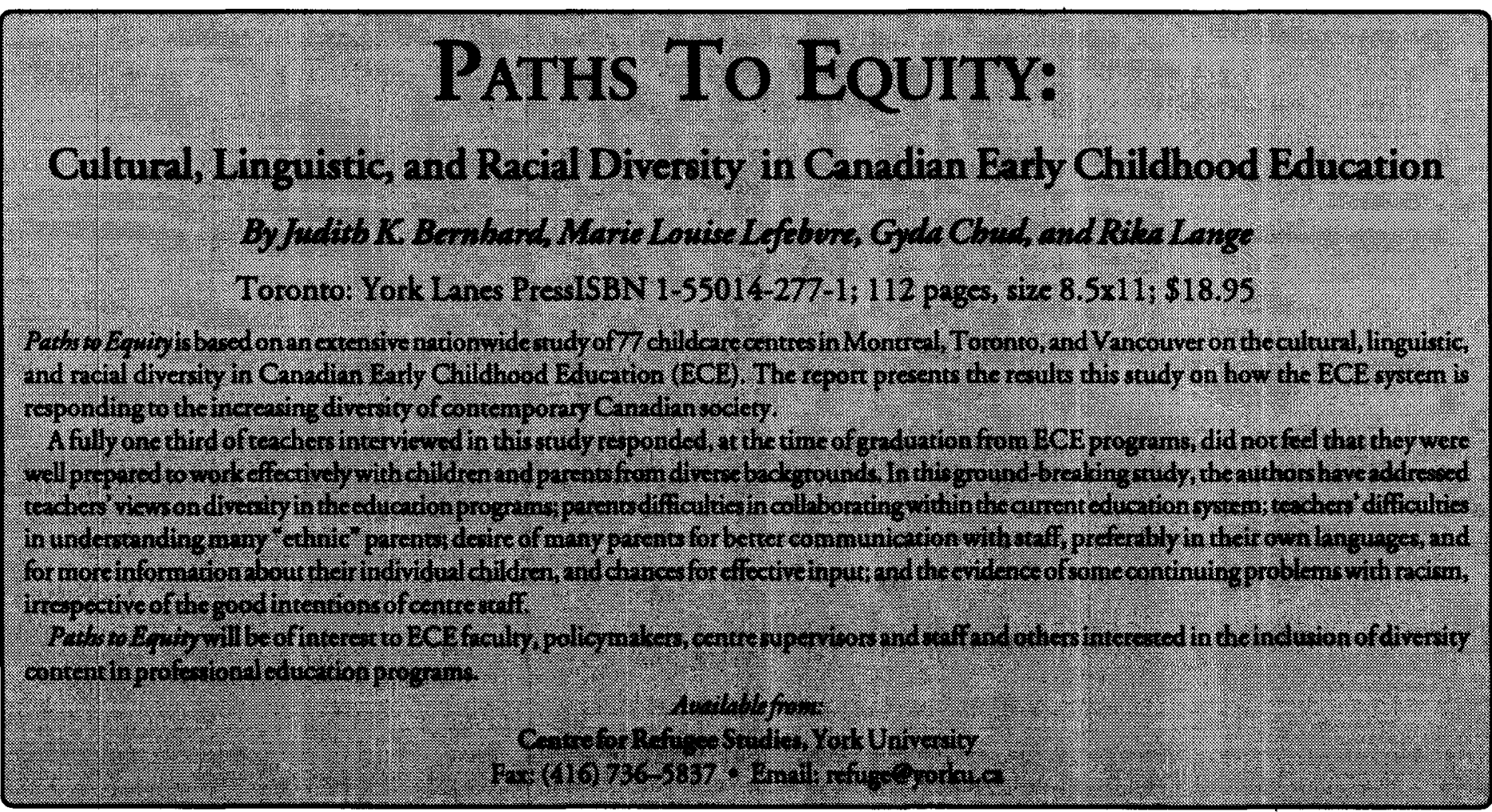




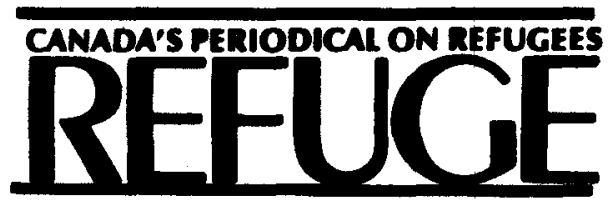

\author{
Refuge \\ Centre for Refugee Studies \\ Suite 322, York Lanes \\ York University \\ 4700 Keele Street, Toronto \\ Ontario, Canada M3J 1P3 \\ Phone: (416) 736-5663
}

Fax: (416) 736-5837

Email: refuge@yorku.ca

\title{
Sunmer Course on Refiugee Issues \\ Toronto, June 6-13, 1999
}

\section{Cowne Ding of SharrymAiken}

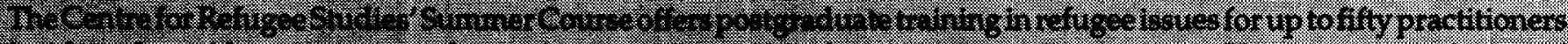

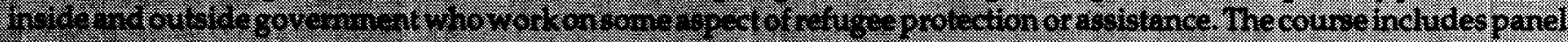

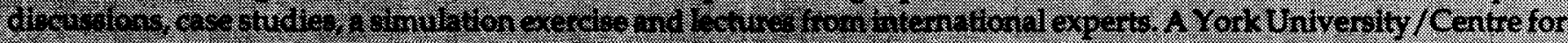

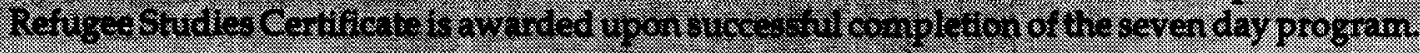

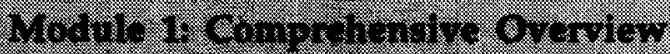

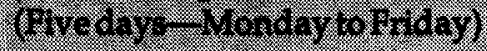

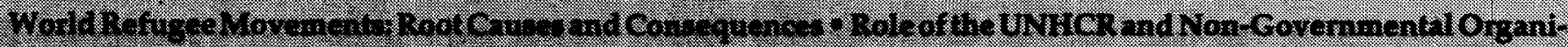

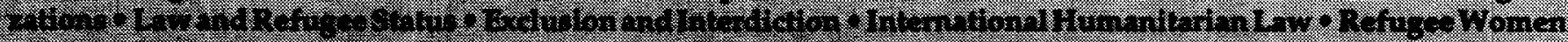

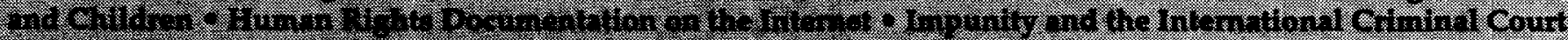
R

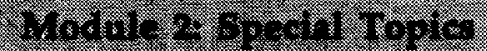

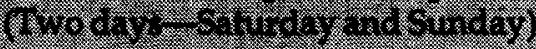

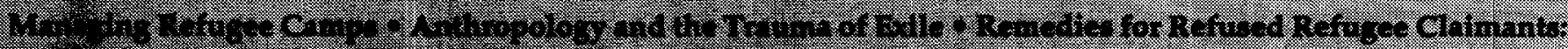

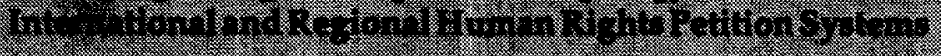

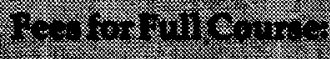

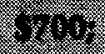
1300

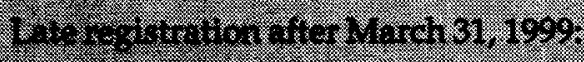
8000

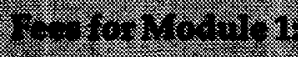

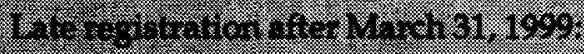

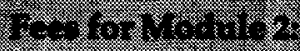
8,0

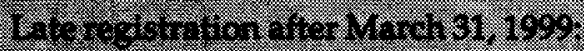
$\$ 550$
8600

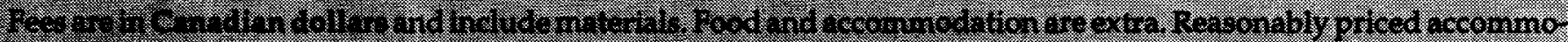

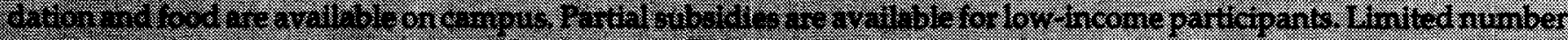

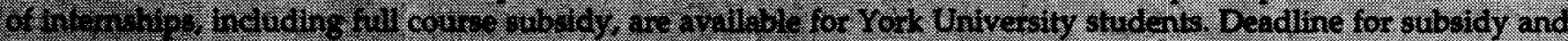

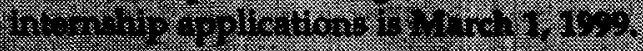

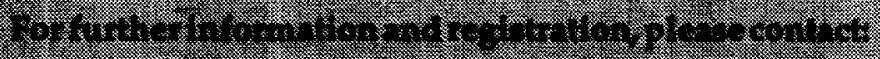

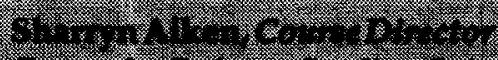

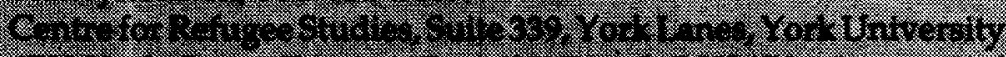

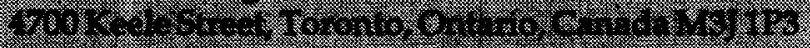

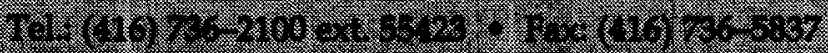

$$
\begin{aligned}
& \text { P. }
\end{aligned}
$$

